\title{
Toxicity analysis of ocular prosthesis acrylic resin with or without pigment incorporation in human conjunctival cell line
}

\author{
Emily Vivianne Freitas da Silva a , Marcelo Coelho Goiato a,*, Liliane da Rocha Bonatto a, \\ Rodrigo Antonio de Medeiros a , Daniela Micheline dos Santos ${ }^{\text {a }}$, \\ Elidiane Cipriano Rangel ${ }^{\mathrm{b}}$, Sandra Helena Penha de Oliveira ${ }^{\mathrm{c}}$
}

a Department of Dental Materials and Prosthodontics, Aracatuba Dental School, Sao Paulo State University (UNESP), Jose Bonifacio St., 1153, Vila Mendonca, Aracatuba, Sao Paulo, Brazil
b Department of Basic Sciences, Aracatuba Dental School, Sao Paulo State University (UNESP), Jose Bonifacio St., 1153, Vila Mendonca, Aracatuba, Sao Paulo, Brazil
c Technological Plasma Laboratory (LaPTec), Experimental Campus of Sorocaba, UNESP, 3 de Marco Av., Alto da Boa Vista, Sorocaba, Sao Paulo, Brazil

\section{A R T I C L E I N F O}

\section{Article history:}

Received 14 April 2016

Received in revised form 5 August 2016

Accepted 8 August 2016

Available online 10 August 2016

\section{Keywords:}

Dental material

Ocular prosthesis

Acrylic resins

Biocompatibility testing

Monomers

\begin{abstract}
A B S T R A C T
The aim of this study was to evaluate the influence of pigment incorporation on the cytotoxicity of ocular prosthesis N1 color acrylic resin. Nine samples were manufactured by heat-polymerization in water bath and divided into 3 groups: acrylic resin without pigment incorporation (group R), acrylic resin with pigment incorporation (group RP), and acrylic pigment (group P). Eluates formed after $72 \mathrm{~h}$ of sample immersion in medium were incubated with conjunctival cell line (Chang conjunctival cells) for $72 \mathrm{~h}$. The negative control group consisted in medium without samples (group C). The cytotoxic effect from the eluates was evaluated using MTT assay (cell proliferation), ELISA assay (quantification of IL1 $\beta$, IL6, TNF $\alpha$ and CCL3/MIP1 $\alpha$ ) and RT-PCR assay (mRNA expression of COL IV, TGF $\beta$ and MMP9). Data were submitted to ANOVA with Bonferroni post-tests $(p<0.05)$. All groups were considered non-cytotoxic based on cell proliferation. However, resin with pigment incorporation showed significant IL6 quantity increase. Resin without pigment incorporation exhibited higher mRNA expression of COL IV, MMP9 and TGF $\beta$, however it was also observed for the negative control group. The materials exhibited divergent biological behavior. Despite the pigment incorporation that resulted in an increase of IL6, no cytotoxicity was observed based on cell proliferation.
\end{abstract}

(c) 2016 Elsevier Ltd. All rights reserved.

\section{Introduction}

The ocular prosthesis is commonly used in anophthalmic patients and is generally made of $\mathrm{N} 1$ acrylic resin, which mimics the patient sclera, and colorless acrylic resin, responsible for the prosthesis characterization covering. The acrylic resin is an option of choice due to its handling and adjustment, satisfactory aesthetics and low cost (Goiato et al., 2012, 2014; Andreotti et al., 2014; Fernandes et al., 2009a).

Acrylic pigments with different colors can be incorporated into acrylic resin for artificial sclera, aiming to simulate the natural sclera of the patient. Moreover, the artificial iris is positioned and red silk fibers may also be incorporated to mimic blood vessels. Then, a thin layer of a colorless resin is used to cover the artificial iris and silk fibers, providing a natural appearance to the prosthesis (Goiato et al., 2010a, 2014).

When the liquid, which consists of a methyl methacrylate (MMA) monomer, is mixed with the powder, an MMA polymer, there is a

\footnotetext{
* Corresponding author at: Department of Dental Materials and Prosthodontics, Aracatuba Dental School, Sao Paulo State University - UNESP, Jose Bonifacio St., 1153, Vila Mendonca, Aracatuba, Sao Paulo 16015-05, Brazil.

E-mail address: goiato@foa.unesp.br (M.C. Goiato).
}

polymerization reaction that consists of the conversion of monomers into polymers, optimizing the physical properties of the material (Bural et al., 2011a). If this reaction is incomplete, residual MMA monomers and other chemicals that can be toxic can be released. Examples of such products are benzoic acid, formaldehyde, and methacrylic acid, among others (Bural et al., 2011a,b; Chaves et al., 2012; Tay et al., 2012; Att et al., 2009; Fernandes et al., 2009b).

Aesthetics, durability and proper adaptation are some of the essential requirements of the ocular prosthesis. However, biocompatibility is a critical characteristic for the success of the treatment and can be evaluated through in vitro cytotoxicity tests, such as the method of cell cultures, which has relatively simple performance and reproduction conditions (Goiato et al., 2010a; Fernandes et al., 2009b; Borra et al. 2009; Jorge et al., 2007; Saravi et al., 2012).

Preferably, primary cells or cell lines, which are closest to the target organ, should be used (Jorge et al., 2007), the use of the cell line from human conjunctiva (Wong Kilbourne derivative of Chang conjunctiva) has been widely reported in in vitro studies of ophthalmic products (Clouzeau et al., 2012; Ayaki et al., 2011a,b, 2012). Therefore, this cell line can be used for the assessment of the cytotoxicity of materials used for ocular prosthesis confection, since its support tissue is the 
conjunctiva, a thin membrane responsible for eye protection (Barisani-Asenbauer et al., 2013; Willoughby et al., 2010).

The biocompatibility of the ocular prosthesis was not previously evaluated, however the necessity to know this property is real and important to guarantee its secure clinical use in patients. Therefore, this study aimed to evaluate the influence of pigment incorporation on the cytotoxicity of ocular prosthesis N1 color acrylic resin. This evaluation was performed through the analysis of the cell proliferation by MTT assay, and the production of proinflammatory cytokines and extracellular matrix proteins by a human conjunctival cell line.

The null hypothesis is that the N1 color acrylic resin, with or without acrylic pigment, and the isolated acrylic pigment do not produce toxic effects on the cell line studied.

\section{Materials and methods}

The number of samples was determined based on previous studies (Bural et al., 2011a; Jorge et al., 2004; Retamoso et al., 2014), and based on the results of a pilot study. A power analysis was performed to determine the number of specimens required for the study, aiming to provide sufficient power (over 95\%). Therefore, 3 samples were used.

Nine samples of materials used for making ocular prosthesis were manufactured by heat-polymerization in water bath (Table 1 ). These samples were divided into 3 groups (Saravi et al., 2012): acrylic resin without pigment incorporation ( $R$, resin), acrylic resin with pigment incorporation ( $R P$, resin with pigment), and acrylic pigment ( $\mathrm{P}$, pigment).

The samples were $10 \mathrm{~mm}$ in diameter and $3 \mathrm{~mm}$ in thickness (Monteiro et al., 2012) and were manufactured through auto-polymerized resin samples, previously obtained from a metallic matrix, which were included in flasks (Artigos Odontológicos Clássico Ltda, Sao Paulo, Brazil) by using type IV dental stone (Durone, Dentsply Ind e Com Ltda, Rio de Janeiro, Brazil) and extra-hard laboratory silicon (Zetalabor, Zhermack, Rovigo, Italy), for embedding the molds. Then, the flasks were opened and the molds were obtained after the samples' removal (Goiato et al., 2010a,b).

The acrylic resin $(\mathrm{R})$ and the isolated acrylic pigment $(\mathrm{P})$ were proportioned and mixed according to the manufacturer's instruction and positioned into the molds contained in the flasks. For the RP group, the incorporation of acrylic pigment was performed during the resin mixing. For this, the acrylic resin and pigment were properly weighed on a precision digital scale (BEL Equipamentos Analítico, Sao Paulo, Brazil) and the pigment was equivalent to $7 \%$ of the acrylic resin weight (Goiato et al., 2013).

After the materials' insertion in the molds contained in the flasks, a counter-flask was positioned and raised in a hydraulic bench press with a $1.250 \mathrm{kgf}$ weight for $2 \mathrm{~min}$ (Goiato et al., 2012). Posteriorly, polymerization was executed according to the manufacturer's instructions, initiated with bench polymerization, immersion of the flask in water

Table 1

Material, commercial brand and chemical composition of the groups.

\begin{tabular}{|c|c|c|}
\hline Material & Commercial brand & Chemical composition \\
\hline $\begin{array}{l}\text { Acrylic } \\
\quad \text { resin } \\
\text { Powder }\end{array}$ & $\begin{array}{l}\text { N1 acrylic resin (Artigos } \\
\text { Odontológicos Clássico Ltda, Sao } \\
\text { Paulo, Brazil) }\end{array}$ & $\begin{array}{l}\text { MMA polymer, } \\
\text { dibuthylftalato, ethyl acrylate, } \\
\text { pigments }\end{array}$ \\
\hline $\begin{array}{l}\text { Acrylic } \\
\text { pigment } \\
\text { Powder }\end{array}$ & $\begin{array}{l}\text { Poli-Côr (color R2) (Artigos } \\
\text { Odontológicos Clássico Ltda, Sao } \\
\text { Paulo, Brazil) }\end{array}$ & $\begin{array}{l}\text { MMA polymer, } \\
\text { dibuthylftalato, ethyl acrylate, } \\
\text { around } 1.5 \% \text { of various organic } \\
\text { and inorganic pigments }\end{array}$ \\
\hline $\begin{array}{l}\text { Acrylic } \\
\text { resin } \\
\text { Liquid }\end{array}$ & $\begin{array}{l}\text { Clássico (Artigos Odontológicos } \\
\text { Clássico Ltda, Sao Paulo, Brazil) }\end{array}$ & MMA monomer, topanol \\
\hline
\end{tabular}

(room temperature), mild heating for $30 \mathrm{~min}$, no heating for $30 \mathrm{~min}$ and boiling for one hour. After these periods, the samples were removed from the flasks and a samples' finishing was performed with a Maxi-Cut abrasive drill (Vicking, Sao Paulo, Brazil).

An additional specimen of each group was used for the analysis of the surface chemical composition. This analysis was performed on small volumes (on the order of $1 \mu \mathrm{m}^{3}$ ), through energy-dispersive spectroscopy (EDS).

For the cytotoxicity analysis, three samples from each group were placed into a sterile vial with $10 \mathrm{~mL}$ of Medium 199 (Gibco, New York, United States) supplemented with $10 \%$ fetal bovine serum (FBS) and incubated at $37^{\circ} \mathrm{C}$ for $72 \mathrm{~h}$. During this period, substances were leached for the medium. Then, the eluates were filtered through $0.22 \mu \mathrm{m}$ filters (Millex, Millipore, Darmstadt, Germany) for sterilization (Att et al., 2009; Jorge et al., 2007; Saravi et al., 2012; International Organization for Standardization [homepage], 2009).

To evaluate the possible toxic effect of substances released by the groups, the cell culture of the human conjunctiva cell line (Wong Kilbourne derivative of Chang conjunctival cell line, clone 1-5c-4) was the selected method. This cell line was obtained from the American Type Culture Collection (CCL-20.2, Virginia, United States). The cells were expanded in flasks with Medium 199. The medium was supplemented with $10 \% \mathrm{FBS}, 10 \mu \mathrm{g} / \mathrm{mL}$ penicillin, $10 \mu \mathrm{g} / \mathrm{mL}$ streptomycin, $10 \mu \mathrm{g} / \mathrm{mL}$ gentamicin and $250 \mu \mathrm{g} / \mathrm{mL}$ fungizone. The cells were incubated with $5 \% \mathrm{CO}_{2}$ and controlled humidity at $37{ }^{\circ} \mathrm{C}$ (Clouzeau et al., 2012; da Silva et al., 2016).

The cells were expanded until cell suspensions of $5 \times 10^{4}$ cells $/ \mathrm{mL}$ were achieved, predetermined by a pilot study. In a 24 well plate, $1 \mathrm{~mL}$ of this suspension was pipetted into each well and after $24 \mathrm{~h}$ of incubation in a humidified atmosphere $\left(5 \% \mathrm{CO}_{2}\right.$ and controlled humidity at $37^{\circ} \mathrm{C}$ in an incubator), the medium was replaced by $500 \mu \mathrm{L}$ of eluates from different groups. Negative control (group C, control) consisted in culture medium with 10\% FBS and without samples (Att et al., 2009; Clouzeau et al., 2012). Medium with Tween 20 (Sigma-Aldrich, Missouri, United States) served as a positive control (group T, Tween). The plate was incubated for $72 \mathrm{~h}$ with the same incubation and temperature conditions determined for generation of the eluates.

The culture medium was discarded and $500 \mu \mathrm{L}$ of Medium 199 without FBS and with $0.5 \mathrm{mg} / \mathrm{mL}$ MTT (3-[4,5-dimethylthiazol-2-yl]-2,5diphenyl tetrazolium bromide) was pipetted into each well. The plate was incubated in the same cited conditions for $4 \mathrm{~h}$ (Att et al., 2009; Jorge et al., 2007; Gonçalves et al., 2008). Later, the culture medium was removed and the intracellular formazan was released by solubilization with $1 \mathrm{~mL}$ of isopropanol per well. The plate was agitated for $5 \mathrm{~min}$ and the absorbance (570 nm) was measured, in triplicate, using a UVvisible spectrophotometer (SpectraMax 190, Molecular Devices, California, United States) (Att et al., 2009; Saravi et al., 2012; Gonçalves et al., 2008).

For the Enzime-linked immune-absorbent assay (ELISA) (DuoSet ELISA Development Systems, R\&D System, Minnesota, United States), the cell-free supernatants were collected after $72 \mathrm{~h}$ of eluate exposition to the cells and the quantification of interleukin $1 \beta$ (IL1 $\beta$ ), interleukin 6 (IL6), tumor necrosis factor $\alpha$ (TNF $\alpha$ ) and, macrophage inflammatory protein $1 \alpha$ (CCL3/MIP1 $\alpha)$ were performed in triplicate (da Silva et al., 2016; Oliveira and Santos, 2011; Trubiani et al., 2012) by using a total volume of $100 \mu \mathrm{L}$ of the supernatant, according to the manufacturer's recommendations.

The real time reverse transcription-polymerase chain reaction (RTPCR) was performed for quantitative analysis of gene expression for type IV collagen (COL IV) (COL4A3BP: Hs00178621_m1), matrix metalloproteinase 9 (MMP9) (MMMP9: Hs00234579_m1) and transforming growth factor $\beta$ (TGF $\beta$ ) (TGFB1: Hs0099133_m1) (da Silva et al., 2016; Oliveira and Santos, 2011), except for the P group.

The P group was not evaluated in the present study, since the acrylic pigment could be incorporated into the resin during the manufacture of the ocular prosthesis, though its use does not occur in an isolated form. 
The total RNA extraction from the cells was performed by using TRIzol reagent (Invitrogen Life Technologies, California, United States), according to the manufacturer's instructions, after $72 \mathrm{~h}$ of eluate exposition to the cells. The RNA concentration was measured through spectrophotometry and the first strand cDNAs were synthesized using $1 \mu \mathrm{g}$ of total RNA and Superscript II RNase $\mathrm{H}^{-}$reverse transcriptase (Invitrogen Life Technologies, California, United States). After this stage, mRNA levels for COL IV, MMP9 and TGF $\beta$ were measured and their amplification was performed by a StepOnePlus Real-Time PCR System (Applied Biosystems, Invitrogen Life Technologies, California, United States). The internal control was the mRNA for $\beta$-actin (ACTB: Hs03023880_g1). The assay was run in duplicate for each sample by using a volume of $20 \mu \mathrm{L}$. The thermal cycling conditions determined by the manufacturer were followed. The results were analyzed using the comparative threshold cycle $\left(C_{T}\right)$ (da Silva et al., 2016).

\subsection{Statistical analysis}

The distribution of each measurement was analyzed for the assumption of normality. Quantitative data were normally distributed. Therefore, one-factor analysis of variance (ANOVA) with Bonferroni posttests $(p<0.05)$ was conducted, using SPSS 21.0 statistics software (IBM Incorporation, New York, United States). The percentage of chemical elements present on the sample surface was compared among groups.

\section{Results}

The percentage of cell proliferation for the materials with different pigmentations evaluated in this study is shown in Fig. 1. Statistical difference was observed between groups $(p=0.000)$. The $\mathrm{R}(88.4 \%)$ and $\mathrm{P}(87.5 \%)$ groups presented lower percentages of cell proliferation, with statistical difference from the C group (100\%).

No detectable levels of IL1 $\beta$ and CCL3/MIP1 $\alpha$ were observed in the present study. On the other hand, high levels of IL6 were found for the tested groups (Fig. 2) and significantly varied according to the material evaluated $(p=0.000)$. Higher concentrations were observed for the RP group $(14.708 \mathrm{pg} / \mathrm{mL})$, when compared to the $\mathrm{C}(9.842 \mathrm{pg} / \mathrm{mL})$ and $\mathrm{P}$ (3.312 pg/mL) groups. No statistical difference was verified in the levels of IL6 between the R group and the C and RP groups.

Fig. 3 Illustrates the absence of statistically significant difference in the levels of TNF $\alpha$ for the materials with different pigmentations evaluated ( $p=0.264)$.

Through Fig. 4, which shows the relative quantification of mRNA for COL IV for the materials tested, a statistical difference was verified between groups ( $p=0.000)$. The $\mathrm{R}(2.21)$ and C (2.01) groups exhibited higher gene expression of COL IV than the RP group (1.25), with statistical difference.

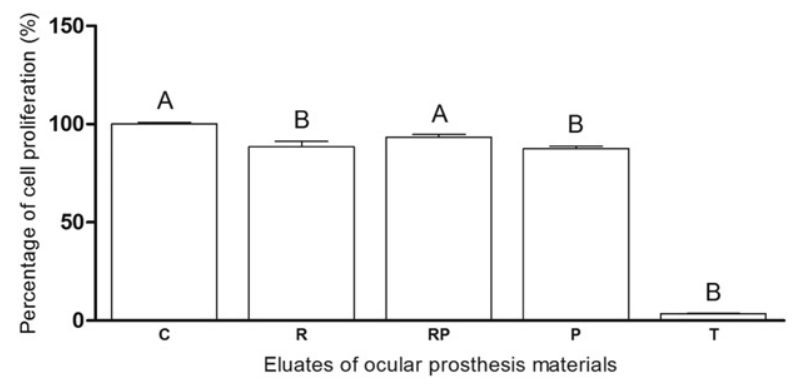

Fig. 1. Percentage of cell proliferation for the evaluated materials. C: negative control group. R: acrylic resin without pigment incorporation. RP: acrylic resin with pigment incorporation. P: acrylic pigment. T: Tween. The results show mean \pm standard error of cell proliferation percentage. Different capital letters indicate statistical difference $(p<0.05)$ compared to the respective group C.

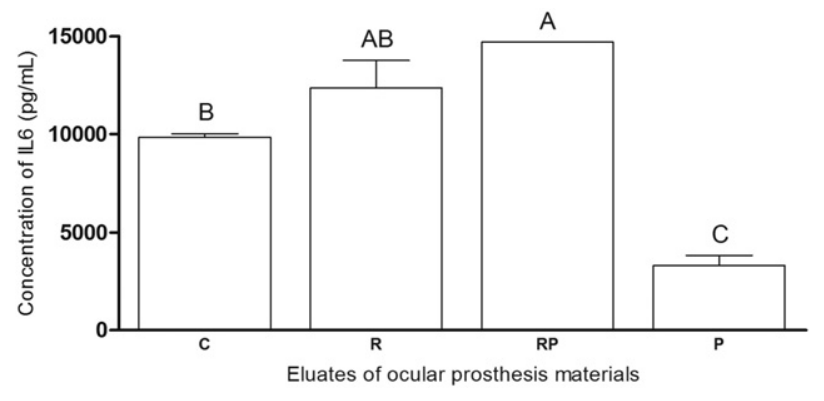

Fig. 2. IL6 concentration for the evaluated materials. C: negative control group. R: acrylic resin without pigment incorporation. RP: acrylic resin with pigment incorporation. P: acrylic pigment. The results show mean \pm standard error of IL6 concentration $(\mathrm{pg} / \mathrm{mL})$. Different capital letters indicate statistical difference $(p<0.05)$ between groups.

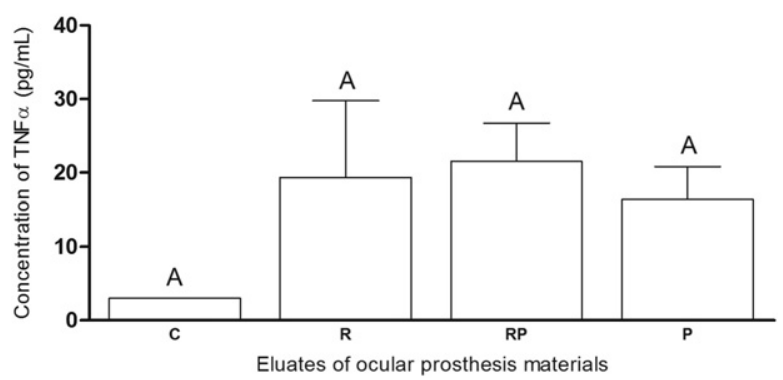

Fig. 3. TNF $\alpha$ concentration for the evaluated materials. C: negative control group. R: acrylic resin without pigment incorporation. RP: acrylic resin with pigment incorporation. P: acrylic pigment. The results show mean \pm standard error of TNF $\alpha$ concentration $(\mathrm{pg} / \mathrm{mL})$. Different capital letters indicate statistical difference $(p<0.05)$ between groups.

Based on Fig. 5, a statistical difference in the relative quantification of mRNA for MMP9 was observed between groups $(p=0.03)$. The $\mathrm{R}$ (5.75) and C (5.77) groups expressed more genes of MMP9 than the RP group (2.95), with statistically significant difference.

Through Fig. 6 , it is possible to observe the relative quantification of mRNA for TGF $\beta$ for the materials tested. There was a statistical difference between the groups ( $p=0.000$ ), wherein the R group (2.02) expressed more genes of TGF $\beta$, when compared to the RP group (1.34).

The chemical elements present on the sample surface were identified by EDS test (Table 2). The elements carbon (C) and oxygen (O) were detected in all groups. The RP group had, in addition, $2.14 \%$ silicon (Si). In the Proup, $1.00 \% \mathrm{Si}$ and $0.13 \%$ aluminum ( $\mathrm{Al}$ ) were found.

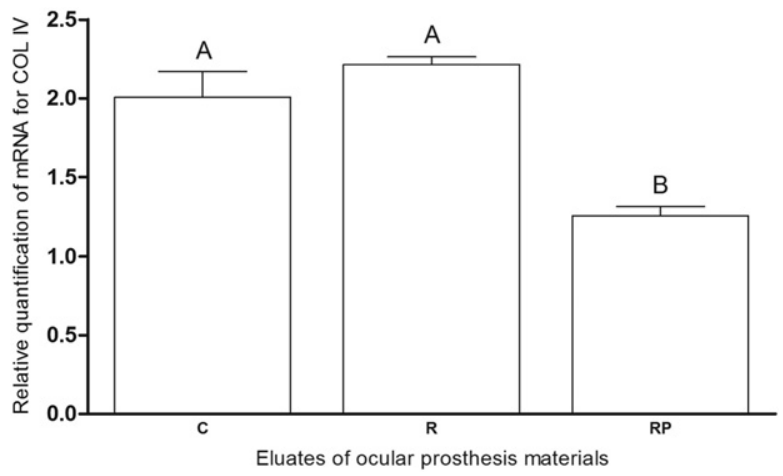

Fig. 4. Relative quantification of mRNA for COL IV for the evaluated materials. C: negative control group. R: acrylic resin without pigment incorporation. RP: acrylic resin with pigment incorporation. P: acrylic pigment. The results show mean \pm standard error of mRNA expression for COL IV. Different capital letters indicate statistical difference $(p<0.05)$ between groups. 


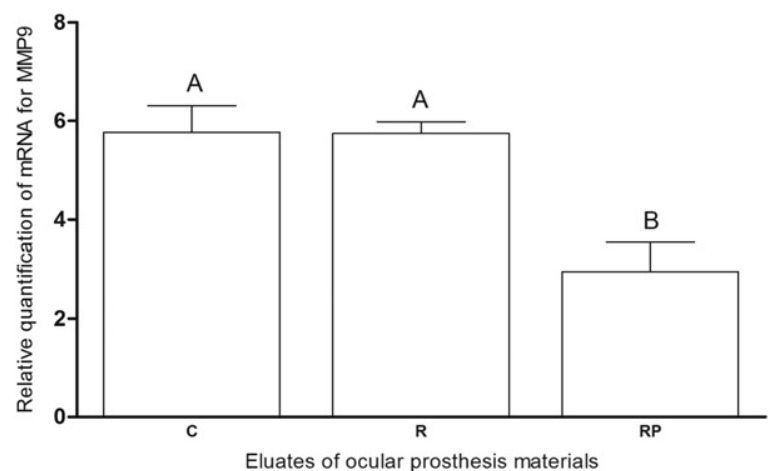

Fig. 5. Relative quantification of mRNA for MMP9 for the evaluated materials. C: negative control group. R: acrylic resin without pigment incorporation. RP: acrylic resin with pigment incorporation. P: acrylic pigment. The results show mean \pm standard error of mRNA expression for MMP9. Different capital letters indicate statistical difference $(p<0.05)$ between groups

\section{Discussion}

The null hypothesis that the N1 color acrylic resin, with or without acrylic pigment, and the isolated acrylic pigment do not produce toxic effects on the cell line studied was not accepted, since the materials with different pigmentations showed divergent behaviors regarding the performed tests.

In the present study, it was observed that all groups had a cell proliferation higher than $75 \%$ (Fig. 1), suggesting that the materials are considered non-cytotoxic, according to ISO 10993-5 standard, which evaluates the in vitro methods for the analysis of cytotoxicity (International Organization for Standardization [homepage], 2009). These results are consistent with the findings from Retamoso et al. (2014), that found that acrylic pigments used in chemically activated resins did not influence the biocompatibility of the material.

Although not cytotoxic, the P group had the lowest percentage of cell proliferation (Fig. 1). This may be associated with the presence of different chemical elements in the composition of the material. Through EDS analysis, the elements aluminum and silicon were detected on the surface of the sample of this group (Table 2).

It is known that aluminum is one of the most abundant elements on the earth's crust in the form of aluminum oxide $\left(\mathrm{Al}_{2} \mathrm{O}_{3}\right)$ (World Health Organization [homepage], 2010). According to the World Health Organization, currently, the tolerable weekly dose is $1 \mathrm{mg}$ of aluminum per kilogram of body weight (World Health Organization [homepage], 2010). Studies have shown that the immune system seems to be sensitive to exposure to $\mathrm{Al}$ (World Health Organization [homepage], 2010;

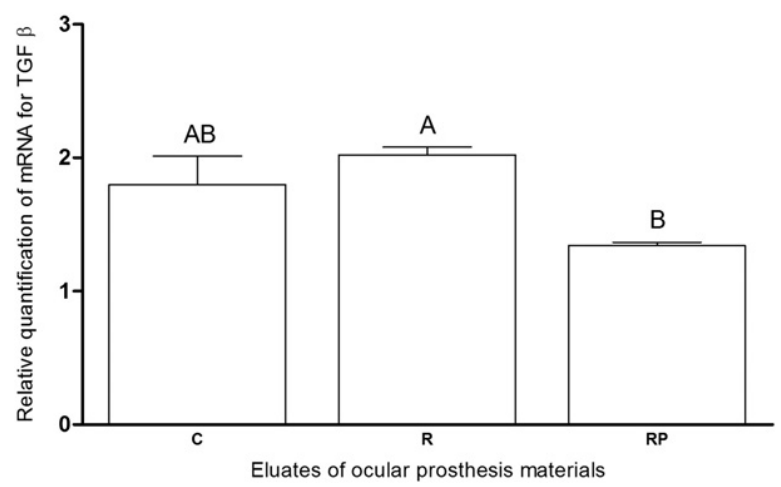

Fig. 6. Relative quantification of mRNA for TGF $\beta$ for the evaluated materials. C: negative control group. R: acrylic resin without pigment incorporation. RP: acrylic resin with pigment incorporation. P: acrylic pigment. The results show mean \pm standard error of mRNA expression for TGF $\beta$. Different capital letters indicate statistical difference $(p<0.05)$ between groups.
Table 2

Percentage (\%) of each chemical compound for the groups assessed by energy-dispersive spectroscopy (EDS)

\begin{tabular}{llll}
\hline & \multicolumn{2}{l}{ Groups } \\
\cline { 2 - 4 } Chemical compound & $\mathrm{R}$ & $\mathrm{RP}$ & $\mathrm{P}$ \\
\hline Carbon & $75.79 \%$ & $74.45 \%$ & $75.02 \%$ \\
Oxygen & $24.21 \%$ & $23.41 \%$ & $23.85 \%$ \\
Silicon & - & $2.14 \%$ & $1.00 \%$ \\
Aluminum & - & - & $0.13 \%$ \\
\hline
\end{tabular}

$\mathrm{R}$ : acrylic resin without pigment incorporation. RP: acrylic resin with pigment incorporation. P: acrylic pigment.

Zhu et al., 2014; Zuh et al., 2013). Some people manifest allergy to aluminum, suffering from dermatitis to its contact, including digestive disorders by eating food cooked in aluminum recipients (World Health Organization [homepage], 2010; Zhu et al., 2014; Zuh et al., 2013). Aluminum is not considered as toxic as heavy metals, but there is some evidence of a certain toxicity when ingested in large quantities, particularly when in the form of ions, because it is soluble in water (World Health Organization [homepage], 2010; Zhu et al., 2014; Zuh et al., 2013). Although the P group was not cytotoxic, the working hypothesis is that cell proliferation may have been reduced due to the presence of aluminum ions.

A statistically significant larger concentration of IL6 for the RP group, when compared to the $\mathrm{C}$ group, was verified (Fig. 2). According to EDS assay, the samples of acrylic resin with acrylic pigment (group RP) presented, besides $\mathrm{C}$ and $\mathrm{O}$, the element $\mathrm{Si}$ (Table 2 ).

The presence of toxic concentrations of metal ions, including silicon, can be associated with genetic alterations, cytotoxicity, inflammatory and carcinogenic reactions (Sargeant and Goswami, 2007). According to Speck-Hernandez and Montoya-Ortiz (2012), the cytotoxic process resulting from the exposure to materials containing silicon include the reduction of cell metabolic activity, the increase of production of inflammatory mediators, such as proinflammatory cytokines (IL1ß, IL6 and TNF $\alpha$ ) and apoptosis. The working hypothesis is that a similar reaction may have occurred in this study, due to the release of silicon ions in the culture medium and their subsequent exposure to the cell culture.

Detectable concentrations of IL1 $\beta$ and CCL3/MIP1 $\alpha$ were not found, suggesting that the stimulus given by the eluates of the tested materials was not sufficient for the Chang conjunctival cells to secrete such inflammatory mediators.

Although no statistically significant difference was found in concentrations of TNF $\alpha$, numerically larger quantities of this mediator can be observed for the evaluated materials when compared to the $C$ group (Fig. 3). TNF $\alpha$ is one of the main pro-inflammatory cytokines and has, together with IL1 and IL6, the ability to increase the local concentration of cells for tissue repair. One of the functions of this mediator is to promote immune and inflammatory responses by recruiting neutrophils and monocytes to the infection site, and activate them (Abbas et al., 2011).

Regarding the relative quantification of MRNA for COL IV, MMP9 and TGF $\beta$, larger amounts of these targets have occurred for the $C$ and $R$ groups (Figs. 4 to 6 ), with no statistically significant difference between them, indicating that the Chang conjunctival cell line seems to produce these targets in physiological condition. Similarity was observed in the increase of gene expression of COL IV and TGF $\beta$ (protein responsible for stimulating COL IV synthesis) (Abbas et al., 2011; Romi et al., 2012). It is known that the balance between the breakage and the synthesis of collagen is essential, while the tissue repair occurs, aiming to avoid fibrous reaction (Tirado-Rodriguez et al., 2014; Santibañez et al., 2011). The COL IV composes the basement membrane extracellular matrix of epithelial cells. It is crucial for a balance to exist in mRNA expression of COL IV, MMP9 and TGF $\beta$, for the preservation of cell structure. However, the expression of MMP9, that acts on the degradation of COL IV (Abbas et al., 2011; Romi et al., 2012), was about three times higher than the expression of the other targets, which can be 
detrimental, since the excessive activation of MMP9 damages cell morphology (Yang et al., 2007).

It is also important to point out that there are basically two techniques of artificial pigmentation of the sclera to try to more naturally simulate the ocular prosthesis, the extrinsic and intrinsic techniques, which may or may not be associated. The extrinsic technique consists of applying pigment on the external surface of the prosthesis base after the acrylization, by using pigments solubilized in MMA monomer that will later be covered by a thin layer of colorless resin. The intrinsic technique is based on the incorporation of small layers of pigment in the acrylic resin mass that will be subsequently polymerized (Goiato et al., 2013). In this study, the intrinsic technique was used and the results obtained did not affect cell proliferation. However, it is necessary to execute further studies to verify the other technique, which may be related or unrelated to the increased release of subproducts, which may cause toxic effects on the cells. Additionally, studies to verify and quantify ions that can be released after polymerization of the studied materials should be performed.

In summary, the materials exhibited divergent biological behavior, regarding cytotoxicity, cell activation and production of matrix proteins. The RP group showed statistically similar results to the $C$ group, regarding cell proliferation and was not cytotoxic, despite increasing the production of IL6.

\section{Conflicts of interest statement}

None declared.

\section{Transparency document}

The Transparency document associated with this article can be found, in online version.

\section{Acknowledgments}

The authors thank CNPq (National Council for Scientific and Technological Development), CAPES (Coordination for the Improvement of Higher Education Personnel) and FAPESP (Foundation for Support to Research of the State of Sao Paulo) (\# 2013/11830-4) for the scholarship granted to the first author.

\section{References}

Abbas, A.K., Lichtman, A.H., Pillai, S., 2011. Cellular and Molecular Immunology. seventh ed. Saunders, Saint Louis (560 pp.).

Andreotti, A.M., Goiato, M.C., Moreno, A., Nóbrega, A.S., Pesqueira, A.A., dos Santos, D.M., 2014. Influence of nanoparticles on color stability, microhardness, and flexural strength of acrylic resins specific for ocular prosthesis. Int. J. Nanomedicine 9, 5779-5787. http://dx.doi.org/10.2147/IJN.S71533 (Dec).

Att, W., Yamada, M., Kojima, N., Ogawa, T., 2009. N-acetyl cysteine prevents suppression of oral fibroblast function on poly(methylmethacrylate) resin. Acta Biomater. 5 (1), 391-398. http://dx.doi.org/10.1016/j.actbio.2008.07.021 (Jan).

Ayaki, M., Iwasawa, A., Niwano, Y., 2011a. Cytotoxicity assays of new artificial tears containing 2-methacryloyloxyethyl phosphorylcholine polymer for ocular surface cells. Jpn. J. Ophthalmol. 55 (5), 541-546. http://dx.doi.org/10.1007/s10384-011-0073-8 (Sep).

Ayaki, M., Iwasawa, A., Yaguchi, S., Koide, R., 2011b. In vitro assessment of the cytotoxicity of anti-allergic eye drops using 5 cultured corneal and conjunctival cell lines. J. Oleo Sci. 60 (3), 139-144. http://dx.doi.org/10.5650/jos.60.139 (Feb).

Ayaki, M., Iwasawa, A., Niwano, Y., 2012. Cell viability score as an integrated indicator for cytotoxicity of benzalkonium chloride-containing antiglaucoma eyedrops. Biocontrol Sci. 17 (3), 121-128. http://dx.doi.org/10.4265/bio.17.121 (Feb).

Barisani-Asenbauer, T., Inic-Kanada, A., Belij, S., Marinkovic, E., Stojicevic, I., Montanaro, J., et al., 2013. The ocular conjunctiva as a mucosal immunization route: a profile of the immune response to the model antigen tetanus toxoid. PLoS One 8 (4), e60682. http://dx.doi.org/10.1371/journal.pone.0060682 (Apr).

Borra, R.C., Lotufo, M.A., Gagioti, S.M., Barros, F., de M Andrade, P.M., 2009. A simple method to measure cell viability in proliferation and cytotoxicity assays. Braz. Oral Res. 23 (3), 255-262. http://dx.doi.org/10.1590/S1806-83242009000300006 (Jul-Sep).

Bural, C., Aktaş, E., Deniz, G., Ünlüçerçi, Y., Bayraktar, G., 2011a. Effect of leaching residual methyl methacrylate concentrations on in vitro cytotoxicity of heat polymerized denture base acrylic resin processed with different polymerization cycles. J. Appl. Oral Sci. 19 (4), 306-312. http://dx.doi.org/10.1590/S1678-77572011005000002 (Aug).
Bural, C., Aktas, E., Deniz, G., Ünlüçerçi, Y., Kızılcan, N., Bayraktar, G., 2011b. Effect of postpolymerization heat-treatments on degree of conversion, leaching residual MMA and in vitro cytotoxicity of autopolymerizing acrylic repair resin. Dent. Mater. 27 (11), 1135-1143. http://dx.doi.org/10.1016/j.dental.2011.08.007 (Nov).

Chaves, C.A., Machado, A.L., Vergani, C.E., de Souza, R.F., Giampaolo, E.T., 2012. Cytotoxicity of denture base and hard chairside reline materials: a systematic review. J. Prosthet. Dent. 107 (2), 114-127. http://dx.doi.org/10.1016/S0022 3913(12)60037-7 (Feb).

Clouzeau, C., Godefroy, D., Riancho, L., Rostène, W., Baudouin, C., Brignole-Baudouin, F., 2012. Hyperosmolarity potentiates toxic effects of benzalkonium chloride on conjunctival epithelial cells in vitro. Mol. Vis. 18, 851-863 (Apr).

da Silva, E.V.F., Goiato, M.C., dos Santos, D.M., Bonatto, L.R., Brito, V.G.B., de Oliveira, S.H.P., 2016. Effect of different methods of polymerizing ocular prosthesis acrylic resin on a human conjunctival cell line. J. Prosthet. Dent. http://dx.doi.org/10.1016/j.prosdent. 2016.06.001 (Jul.).

Fernandes, A.U.R., Goiato, M.C., Batista, M.A.J., Santos, D.M., 2009a. Color alteration of the paint used for iris painting in ocular prostheses. Braz. Oral Res. 23 (4), 386-392. http://dx.doi.org/10.1590/S1806-83242009000400007 (Oct-Dec).

Fernandes, A.U., Portugal, A., Veloso, L.R., Goiato, M.C., Santos, D.M., 2009b. Assessment of the flexural strength of two heat-curing acrylic resins for artificial eyes. Braz. Oral Res. 23 (3), 263-267. http://dx.doi.org/10.1590/S180683242009000300007 (Jul-Sep).

Goiato, M.C., Santos, D.M., Souza, J.F., Moreno, A., Pesqueira, A.A., 2010a. Chromatic stability of acrylic resins of artificial eyes submitted to accelerated aging and polishing. J. Appl. Oral Sci. 18 (6), 641-645. http://dx.doi.org/10.1590/S167877572010000600018 (Nov-Dec)

Goiato, M.C., Santos, D.M., Haddad, M.F., Pesqueira, A.A., 2010b. Effect of accelerated aging on the microhardness and color stability of flexible resins for dentures. Braz. Oral Res. 24 (1), 114-119. http://dx.doi.org/10.1590/S1806-83242010000100019 (Jan-Mar).

Goiato, M.C., Dos Santos, D.M., Moreno, A., Iyda, M.G., Rezende, M.C., Haddad, M.F., 2012. Effect of disinfection and storage on the flexural strength of ocular prosthetic acrylic resins. Gerodontology 29 (2), e838-e844. http://dx.doi.org/10.1111/j.1741-2358. 2011.00570.x (Jun).

Goiato, M.C., Zuccolotti, B.C.R., Santos, D.M., Sinhoreti, A.C., Moreno, A., 2013. Effect of intrinsic nanoparticle pigmentation on the color stability of denture base acrylic resins J. Prosthet. Dent. 110 (2), 101-106. http://dx.doi.org/10.1016/S00223913(13)60387-X (Aug).

Goiato, M.C., Bannwart, L.C., Haddad, M.F., dos Santos, D.M., Pesqueira, A.A., Miyahara, G.I., 2014. Fabrication techniques for ocular prostheses - an overview. Orbit 33 (3), 229-233. http://dx.doi.org/10.3109/01676830.2014.881395 (Jun).

Gonçalves, T.S., Schmitt, V.M., Thomas, M., de Souza, M.A.L., de Menezes, L.M., 2008. Cytotoxicity of two autopolymerized acrylic resins used in orthodontics. Angle Orthod. 78 (5), 926-930. http://dx.doi.org/10.2319/072407-343.1 (Sep).

International Organization for Standardization [homepage], 2009,. ISO 10993-5: Biological Evaluation of Medical Devices - Part 5: Tests for in vitro Cytotoxicity. ISO, Geneva ([cited 2009 Jun 01]. Available from: http://www.iso.org/iso/catalogue_detail.htm? csnumber $=36406$ ).

Jorge, J.B., Giampaolo, E.T., Vergani, C.E., Machado, A.L., Pavarina, A.C., Carlos, I.Z., 2004. Cytotoxicity of denture base resins: effect of water bath and microwave postpolymerization heat treatments. Int. J. Prosthodont. 17 (3), 340-344 (May-Jun).

Jorge, J.H., Giampaolo, E.T., Vergani, C.E., Machado, A.L., Pavarina, A.C., Carlos, I.Z., 2007 Biocompatibility of denture base acrylic resins evaluated in culture of L929 cells. Effect of polymerisation cycle and post-polymerisation treatments. Gerodontology 24 (1), 52-57. http://dx.doi.org/10.1111/j.1741-2358.2007.00146.x (Mar).

Monteiro, D.R., Gorup, L.F., Takamiya, A.S., de Camargo, E.R., Filho, A.C., Barbosa, D.B., 2012. Silver distribution and release from an antimicrobial denture base resin containing silver colloidal nanoparticles. J. Prosthodont. 21 (1), 7-15. http://dx.doi.org/10. 1111/j.1532-849X.2011.00772.x (Jan).

Oliveira, S.H., Santos, V.A., 2011. Studies on the expression of fibroblast growth factor-2 from odontoblast-like cells. J. Endod. 37 (11), 1520-1524. http://dx.doi.org/10. 1016/j.joen.2011.08.004 (Nov).

Retamoso, L.B., Cunha, T.M.A., Pithon, M.M., Santos, R.L., Martins, F.O., Romanos, M.T.V., et al., 2014. In vitro cytotoxicity of self-curing acrylic resins of different colors. Dent Press J. Orthod. 19 (4), 66-70. http://dx.doi.org/10.1590/2176-9451.19.4.066-070. oar (Jul-Aug).

Romi, F., Helgeland, G., Gilhus, N.E., 2012. Serum levels of matrix metalloproteinases: implications in clinical neurology. Eur. Neurol. 67 (2), 121-128. http://dx.doi.org/10. 1159/000334862 (Jan).

Santibañez, J.F1., Quintanilla, M., Bernabeu, C., 2011. TGF- $\beta /$ TGF- $\beta$ receptor system and its role in physiological and pathological conditions. Clin. Sci. (Lond.) 121 (6), 233-251. http://dx.doi.org/10.1042/CS20110086 (Sep).

Saravi, M.E., Vojdani, M., Bahrani, F., 2012. Evaluation of cellular toxicity of three denture base acrylic resins. J. Dent. 9 (4), 180-188 (Fall).

Sargeant, A., Goswami, T., 2007. Hip implants - Paper VI - Ion concentrations. Mater. Des. 28 (1), 155-171. http://dx.doi.org/10.1016/j.matdes.2005.05.018 (Jul).

Speck-Hernandez, C.A., Montoya-Ortiz, G., 2012. Silicon, a possible link between environmental exposure and autoimmune diseases: the case of rheumatoid arthritis. Arthritis 2012, 604187. http://dx.doi.org/10.1155/2012/604187.

Tay, L.Y., Herrera, D.R., Quishida, C.C., Carlos, I.Z., Jorge, J.H., 2012. Effect of water storage and heat treatment on the cytotoxicity of soft liners. Gerodontology 29 (2), e275-e280. http://dx.doi.org/10.1111/j.1741-2358.2011.00463.x (Jun).

Tirado-Rodriguez, B., Ortega, E., Segura-Medina, P., Huerta-Yepez, S., 2014. TGF- $\beta$ : an important mediator of allergic disease and a molecule with dual activity in cancer development. J. Immunol. Res. 2014, 318481. http://dx.doi.org/10.1155/2014/318481 (Jun). 
Trubiani, O., Toniato, E., Di Iorio, D., Diomede, F., Merciaro, I., D'Arcangelo, C., et al., 2012 Morphological analysis and interleukin release in human gingival fibroblasts seeded on different denture base acrylic resins. Int. J. Immunopathol. Pharmacol. 25 (3) 637-643 (Jul-Sep).

Willoughby, C.E., Ponzin, D., Ferrari, S., Lobo, A., Landau, K., Omido, Y., 2010. Anatomy and physiology of the human eye: effects of mucopolysaccharidoses disease on structure and function - a review. Clin. Exp. Ophthalmol. 38 (Supp1), 2-11. http://dx.doi.org/ 10.1111/j.1442-9071.2010.02363.x (Aug).

World Health Organization [homepage], 2010. Aluminium in Drinking-Water. Background Document for Development of WHO Guidelines for Drinking-Water Quality. World Health Organization, Geneva ([cited 2010]. Available from: http://www.who. int/water_sanitation_health/publications/aluminium/en/).
Yang, K., Palm, J., König, J., Seeland, U., Rosenkranz, S., Feiden, W., et al., 2007. MatrixMetallo-Proteinases and their tissue inhibitors in radiation-induced lung injury. Int. J. Radiat. Biol. 83 (10), 665-676. http://dx.doi.org/10.1080/09553000701558977 (Oct).

Zhu, Y., Li, Y., Miao, L., Wang, Y., Liu, Y., Yan, X., et al., 2014. Immunotoxicity of aluminum. Chemosphere 104, 1-6. http://dx.doi.org/10.1016/j.chemosphere.2013.10.052 (Jun).

Zuh, Y.Z., Liu, D.W., Liu, Z.Y., Li, Y.F., 2013. Impact of aluminum exposure on the immune system: a mini review. Environ. Toxicol. Pharmacol. 35 (1), 82-87. http://dx.doi.org/ 10.1016/j.etap.2012.11.009 (Jan). 